Case Report

\title{
Gastric xanthelasma: case report
}

\section{Ana C. Almeida*, Emília C. Fraga, Cristina P. Camacho, Maria J. Amaral, António Milheiro, António Bernardes, José G. Tralhão}

Department of Surgery, Centro Hospitalar e Universitário de Coimbra, Coimbra, Portugal

Received: 14 December 2019

Accepted: 08 January 2020

\section{*Correspondence:}

Dr. Ana Catarina Almeida,

E-mail: ana.cdo.almeida@gmail.com

Copyright: ( ) the author(s), publisher and licensee Medip Academy. This is an open-access article distributed under the terms of the Creative Commons Attribution Non-Commercial License, which permits unrestricted non-commercial use, distribution, and reproduction in any medium, provided the original work is properly cited.

\begin{abstract}
Xanthelasma, also known as Xanthoma or lipid island, is an uncommon gastrointestinal tract (GIT) tumor-like lesion and the stomach is its most frequent location in upper GI lesions, specifically in the gastric antrum, as a single lesion. The pathogenesis appears to be related to healing processes in response to tissue damage provoked by inflammation induced by Helicobacter pylori infection. Many studies have reported that successful H. pylori eradication helps prevent gastric cancer (GC) development. We present a case of a 77 years old patient that showed endoscopic diagnosis of erythematous gastropathy, a gastric antrum xanthelasma and H. Pylori infection. After confirmed H. pylori eradication, the lesion had complete regression. The successful eradication of $H$. pylori probably led to a total regression of the lesion. Gastric xanthelasma (GX) has been shown to be an independent predictive marker for early GC detection after $H$. pylori eradication. GX could be a useful marker for predicting the development of gastric cancer.
\end{abstract}

Keywords: Xanthelasma, Xanthoma, Gastric cancer, Marker, H. pylori, Inflammatory response

\section{INTRODUCTION}

Xanthelasma, also known as xanthoma or lipid island, is an uncommon gastrointestinal tract (GIT) tumor-like lesion and the stomach is the most common site of reported upper GIT lesions, specifically in the gastric antrum, as a single lesion. ${ }^{1-6}$ Gastric xanthelasma (GX) is a rare, non-neoplastic finding with a prevalence ranging from 0.2 to $7 \% .^{1-3}$ The pathogenesis of GX is not clear, however it appears to be related to healing processes in response to tissue damage provoked by inflammation induced by Helicobacter pylori infection. ${ }^{1,4}$ Endoscopically, these lesions usually present as welldemarcated round, yellow- white nodules or plaques, resembling certain malignant lesions. ${ }^{1,6}$ Microscopically, GX is characterized by collections of foamy macrophages in the lamina propria, secondary to phagocytosis of the bacteria. Histological confirmation of GX is mandatory because its appearance may mimic malignancy and once the histological diagnosis of GX is confirmed, it is necessary to look for accompanying premalignant conditions. ${ }^{1}$ Metabolic and inflammatory factors were found associated with xanthelasma. Other factors such as fasting plasma glucose, neutrophil, and carcinoembryonic antigen (CEA) were proved to be independent factors for GX occurrence. ${ }^{2}$

\section{CASE REPORT}

A 77-year old man presenting with nonspecific abdominal pain is referred to our Surgical Department with the endoscopic diagnosis of erythematous gastropathy and an xanthelasma located at the antral region, specifically in the lesser curvature. Biopsy were sent to histopathological analysis, and they confirmed the endoscopic diagnosis. H. pylori infection was also present. 
The patient then underwent $H$. pylori eradication. The follow-up endoscopy showed a complete regression of GX and confirmed the eradication of H. Pylori.

Maintains follow-up with annual endoscopy and is now asymptomatic.

\section{DISCUSSION}

Xanthoma's etiology and clinical significance are still unclear. However, several studies have identified GX as an independent predictor for gastric cancer (GC) development. ${ }^{4,6}$ Atrophy-matched control analysis was singled out and the incidence of gastric xanthelasma has been shown to be significantly higher in patients with diabetes mellitus. ${ }^{3,4,7}$ The diagnosis should be confirmed in order to eliminate the possibility of gastric malignancy. ${ }^{8}$

In our case, xanthoma was diagnosed in an elderly male patient, where erythematous gastropathy was present. He had no history of diabetes mellitus, but the lipid status was not studied. The successful eradication of $H$. pylori led to a total regression of the lesion.

Many studies have reported that successful $H$. pylori eradication helps prevent gastric cancer development. GX has been shown to be an independent predictive marker for early GC detected after $H$. pylori eradication. ${ }^{5}$

\section{CONCLUSION}

Gastric xanthelasma (GX) has been under looked, as it has been considered a benign lesion. As gastric cancer is still one of the leading causes of cancer-related deaths worldwide, GX could be a very useful marked for predicting the development of gastric cancer and GX seems to be treated or even cured with $H$. pylori's eradication.

Funding: No funding sources Conflict of interest: None declared Ethical approval: Not required

\section{REFERENCES}

1. Alzahrani M, Alqunaitir A, Alsohaibani M, AlRikabi AC. Gastric xanthelasma associated with hyperplastic polyp and mucosal erosions: report of an unusual case and literature review. Oxf Med Case Reports. 2018;2018(8):omy051.

2. Chen Y, He XJ, Zhou MJ, Li YM. Gastric xanthelasma and metabolic disorders: A large retrospective study among Chinese population. World J Gastroenterol. 2017;23(43):7756-64.

3. Sekikawa A, Fukui H, Sada R, Fukuhara M, Marui S, Tanke G, et al. Gastric atrophy and xanthelasma are markers for predicting the development of early gastric cancer. J Gastroenterol. 2016;51:35.

4. Hori S, Tsutsumi Y. Helicobacter pylori infection in gastric xanthomas: immunohistochemical analysis of 145 lesions. Pathol Int. 1996;46(8):589-93

5. Shibukawa N, Ouchi S, Wakamatsu S, Wakahara Y, Kaneko A. Gastric Xanthoma Is a Predictive Marker for Early Gastric Cancer Detected after Helicobacter pylori Eradication. Intern Med. 2019;58(6):779-84.

6. Sekikawa A, Fukui H, Maruo T, Tsumura T, Kanesaka T, Okabe Y, et al. Gastric xanthelasma may be a warning sign for the presence of early gastric cancer. J Gastroenterol Hepatol. 2014;29(5):951-6.

7. Kitamura S, Muguruma N, Okamoto K, Tanahashi T, Fukuya A, Tanaka K, et al. Clinicopathological assessment of gastric xanthoma as potential predictive marker of gastric cancer. Digestion. 2017;96(4):199-206.

8. Andrejić BM, Božanić SV, Solajić NS, Djolai MA, Levakov AM. Xanthomas of the stomach: a report of two cases. Bosn J Basic Med Sci. 2012;12(2):127-9.

Cite this article as: Almeida AC, Fraga E, Camacho C, Amaral MJ, Milheiro A, Bernardes A, et al. Gastric xanthelasma: case report. Int Surg J 2020;7:594-5. 